\title{
STIGMA MASYARAKAT TERHADAP PENYINTAS COVID-19 DI KECAMATAN DUREN SAWIT, JAKARTA TIMUR
}

\author{
Risa Laras Wati ${ }^{1}$, Ella Nurlaella Hadi $^{2}$ \\ Program Pascasarjana Ilmu Kesehatan Masyarakat ${ }^{1}$ \\ Departemen Pendidikan Kesehatan dan Ilmu Perilaku, Fakultas Kesehatan Masyarakat ${ }^{2}$ \\ Universitas Indonesia \\ risalaraswati18@gmail.com ${ }^{1}$, ellanhadi28@gmail.com ${ }^{2}$
}

\begin{abstract}
East Jakarta City is the largest and most populous area in DKI Jakarta. Disease transmission can be accelerated in densely populated urban environments. As of August 11, 2021, East Jakarta had the largest number of COVID-19 cases, 206.001, while Duren Sawit Sub-district had the highest number of cases in DKI Jakarta, with 28,496 persons. The ongoing COVID-19 outbreak has led in a variety of responses to the information that is now available. As a result, numerous public stigmas have developed. Excessive awareness, worry, and terror emerge from disinformation, which isn't matched by empathy and understanding for COVID-19 survivors. The purpose of this study was to analyze the community's stigma against COVID-19 survivors in Duren Sawit District. In-depth interviews were conducted as part of this study's qualitative research methodology. The informants in this study were ten people: four people who were COVID-19 survivors' neighbors, three COVID-19 survivors, and the families of survivors who resided in the same house as COVID-19 survivors in Duren Sawit District. In Duren Sawit District, survivors and families of COVID-19 survivors faced a negative stigma from the community. In Duren Sawit District, survivors and families of COVID-19 survivors faced a negative stigma from the community. As a result, the government, health practitioners, and community leaders must all play a part in providing COVID-19 education so that the community remains supportive and survivors are not stigmatized.
\end{abstract}

Keyword $\quad$ :COVID-19, public, stigma, survivor COVID-19

\begin{abstract}
ABSTRAK
Kota Jakarta Timur merupakan wilayah terluas di DKI Jakarta dengan jumlah penduduk tertinggi. Wilayah perkotaan dengan kepadatan penduduk yang tinggi dapat menyebabkan transmisi penyakit lebih cepat. Jakarta Timur memiliki jumlah kasus COVID-19 tertinggi yaitu 206.001 dan Kecamatan Duren Sawit merupakan kecamatan dengan jumlah kasus tertinggi di DKI Jakarta sebanyak 28.496 jiwa per tanggal 11 Agustus 2021. Wabah COVID-19 yang belum berakhir mengakibatkan berbagai informasi yang tersedia saat ini ditanggapi dengan beragam respon, sehingga berkembang berbagai stigma publik. Disinformasi mengakibatkan kewaspadaan, kecemasan, dan ketakutan berlebihan yang tidak diimbangi dengan empati dan simpati terhadap korban. Tujuan dari penelitian ini adalah menganalisis stigma masyarakat terhadap penyintas COVID-19 di Kecamatan Duren Sawit. Penelitian ini menggunakan metode penelitian kualitatif dengan melakukan wawancara mendalam. Informan dalam penelitian ini terdiri dari 10 informan yang terdiri dari: empat orang yang merupakan tetangga dari penyintas COVID-19, tiga orang penyintas COVID-19 serta keluarga penyintas yang tinggal dalam satu rumah dengan penyintas COVID-19 di Kecamatan Duren Sawit. Terjadi stigma negatif yang diberikan oleh masyarakat baik kepada penyintas maupun keluarga penyintas COVID-19 di Kecamatan Duren Sawit. Untuk itu, diperlukan peranan pemerintah, praktisi kesehatan, dan tokoh masyarakat dalam memberikan edukasi terkait COVID-19 agar masyarakat tetap mendukung dan tidak memberi stigma negatif kepada penyintas.
\end{abstract}

Kata Kunci : COVID-19, Masyarakat, Penyintas COVID-19, Stigma 


\section{PENDAHULUAN}

Pada akhir tahun 2019 dunia digemparkan oleh munculnya virus yang berbahaya di kota Wuhan, Provinsi Hubei Tiongkok (Dai, 2020). Virus tersebut diberi nama Novel Coronavirus (SARS-CoV-2) dan penyakitnya dikenal sebagai Coronavirus Disease 2019 (COVID-19). Coronavirus adalah keluarga besar virus yang diketahui menyebabkan penyakit mulai dari flu biasa hingga penyakit yang lebih parah seperti Middle East Respiratory Syndrome (MERS) dan Severe Acute Respiratory Syndrome (SARS) (WHO, 2020). Virus ini dapat berpindah dari satu orang ke orang lain, faktor terpenting dalam penularan virus ini adalah melalui saluran pernafasan dan sentuhan atau kontak (Lai et al., 2020).

Pada tanggal 11 Agustus 2021 World Health Organization (WHO) melaporkan bahwa terdapat 203.900.000 jiwa angka terkonfimasi positif COVID-19 di dunia (World Health Organization, 2021). Data di Indonesia menunjukkan bahwa sampai dengan tanggal 11 Agustus 2021 sudah mencapai 3.718.821 jiwa yang terkonfirmasi positif COVID-19. Angka kasus konfirmasi positif COVID-19 di DKI Jakarta sebesar 833.651 jiwa. Angka terkonfirmasi positif COVID-19 semakin meningkat setiap harinya dan belum menunjukkan penurunan (Kementrian Kesehatan RI, 2021)

Selain masalah kesehatan secara umum, terdapat masalah lain yang timbul pada penderita COVID-19 yaitu stigma. Stigma adalah label sosial yang membuat para penderita COVID-19 tidak dapat diterima masyarakat di tempat mereka tinggal (Baldassarre et al., 2020). Pandemi COVID19 yang belum berakhir mengakibatkan informasi yang tersedia terkait pandemi ini ditanggapi dengan beragam respon di kalangan masyarakat Indonesia, sehingga berkembang berbagai stigma publik dan disinformasi mengakibatkan kewaspadaan, kecemasan, dan ketakutan berlebihan yang tidak diimbangi dengan empati dan simpati terhadap korban (Sulistiadi et al., 2020).
Pemerintah melakukan upaya untuk meredam gejolak masyarakat dengan berbagai kebijakan tetapi pemerintah sendiri belum memberikan informasi yang memadai untuk meningkatkan pemahaman masyarakat (Sulistiadi et al., 2020). Di beberapa daerah, kasus stigma berkembang di sekitar pasien COVID-19, keluarga pasien, dan petugas kesehatan dan seiring berjalannya waktu, kekhawatiran akan stigma yang terkait dengan pandemi COVID-19 menjadi lebih mengerikan daripada virus itu sendiri. Selain itu, adanya stigma dapat berdampak langsung pada kondisi kesehatan mental seseorang yang distigmasasi (Laras Widyaningrum, 2020, Islam et al., 2021).

Adanya pemberitaan tentang COVID-19 pada media sosial membuat kesadaran dan kewaspadaan masyarakat terkait bahaya COVID-19 semakin meningkat, namun hal tersebut juga menimbulkan rasa takut yang berlebihan, hilangnya rasa solidaritas untuk sama-sama memutus rantai penularan COVID-19, serta stigma negatif pada penyintas (Sulistiadi et al., 2020). Dalam konteks pandemi COVID-19, stigma merupakan ancaman besar ketika seseorang yang dinyatakan positif terinfeksi COVID-19 terlanjur diberi label sebagai pembawa penyakit dan membahayakan bagi orangorang disekitarnya, sehingga seorang pasien berpotensi mengalami pengucilan dalam jangka waktu lama (Rahman et al., 2021). Suatu penelitian yang dilakukan di Upazila menunjukkan bahwa sebagian masyarakat memiliki respon negatif setelah mengetahui ada anggota keluarga tenaga medis di lingkungan tempat tinggal mereka yang terinfeksi COVID-19 (Mahmud \& Islam, 2020). Penelitian di Yogyakarta menunjukkan 63.4\% masyarakat memiliki sikap stigma cukup tinggi dan $33.7 \%$ memiliki sikap stigma tinggi (Rahman et al., 2021).

Kota Jakarta Timur merupakan wilayah terluas di Provinsi DKI Jakarta yaitu sebesar 188.03 KM2 dengan jumlah penduduk tertinggi diantara wilayah DKI lainnya yaitu sebesar 2.937.859 orang pada tahun 2019 (Badan Pusat Statistik, 2020). Kepadatan penduduk merupakan salah satu pemicu 
dalam penyebaran COVID-19. Kawasan perkotaan dengan tingkat kepadatan penduduk yang tinggi dibandingkan daerah pinggiran akan menyebabkan transmisi penyakit lebih cepat (Izham, 2021). Tingginya mobilitas penduduk mengakibatkan wilayah Jakarta Timur memiliki jumlah kasus tertinggi yaitu 206.001 jiwa terkonfirmasi positif COVID-19 (Mashabi, 2020). Kecamatan Duren Sawit yang berada di Jakarta Timur merupakan kecamatan dengan jumlah kasus positif tertinggi di Provinsi DKI Jakarta dengan jumlah kasus sebesar 28.496 jiwa per tanggal 11 Agustus 2021 (Pemprov DKI Jakarta, 2021). Sebagai penyakit baru yang cepat menular dan menyebar dan disertai dengan membanjirnya informasi melalui media sosial, yang tidak semuanya bisa dipercaya, telah menimbulkan stigma bagi masyarakat yang berkaitan dengan COVID-19 (Setiawati et al., 2020). Tujuan dari penelitian ini adalah mengetahui gambaran stigma masyarakat Kecamatan Duren Sawit pada pasien COVID19.

\section{METODE}

Penelitian ini menggunakan metode penelitian kualitatif untuk mencari jawaban atas pertanyaan mengapa dan bagaimana stigma terhadap penderita COVID-19. Pengumpulan dan analisis data dilakukan untuk mengeksplorasi masalah yang terkait dengan bagaimana perasaan para penyintas saat dinyatakan positif COVID-19, stigma terhadap penyintas COVID-19, stigma terhadap keluarga penyintas COVID-19, persepsi masyarakat tentang penyintas COVID-19, dan persepsi masyarakat tentang keluarga penyintas COVID-19 di Kecamatan Duren Sawit.

Informan dalam penelitian ini terdiri dari 10 informan yang terdiri dari: empat orang tetangga dari penyintas COVID-19, yang terdiri dari 3 orang laki-laki dan seorang perempuan, tiga orang penyintas COVID-19 berjenis kelamin 2 orang perempuan dan seorang laki-laki serta keluarga penyintas yang merupakan orang tua dan kakak yang tinggal satu rumah dengan penyintas di Kecamatan Duren Sawit. Penelitian ini berlangsung selama pandemi COVID-19 dengan melakukan wawancara mendalam melalui Video Call Whatsapp/Zoom. Sebelum wawancara dilakukan para informan telah dijelaskan secara singkat tentang tujuan penelitian serta mengisi informed consent.

Hasil wawancara disusun dalam bentuk transkrip kemudian dilakukan pengkodean agar setiap topik mudah dianalisa. Transkrip yang sudah disusun dan diberi kode kemudian dimuat dalam bentuk matriks dan selanjutnya dilakukan analisis isi.

\section{HASIL}

Informan penelitian ini adalah masyarakat dari Kecamatan Duren Sawit yang terdiri dari tiga orang penyintas COVID-19, tiga orang keluarganya, dan empat orang tetangganya. Berikut merupakan tabel karakteristirk informan.

Tabel 1. Karakteristik Informan

\begin{tabular}{|c|c|c|c|}
\hline $\begin{array}{c}\text { Jenis } \\
\text { Kelamin }\end{array}$ & Usia & Pendidikan & Status \\
\hline Perempuan & 26 & S1 & Penyintas \\
\hline Laki-laki & 24 & D3 & Penyintas \\
\hline Perempuan & 24 & S1 & Penyintas \\
\hline Perempuan & 57 & SMA & $\begin{array}{c}\text { Keluarga } \\
\text { Penyintas } 1\end{array}$ \\
\hline Laki-laki & 32 & S1 & $\begin{array}{c}\text { Keluarga } \\
\text { Penyintas } 2\end{array}$ \\
\hline Perempuan & 61 & S1 & $\begin{array}{c}\text { Keluarga } \\
\text { Penyintas } 3\end{array}$ \\
\hline Laki-laki & 31 & $\mathrm{~S} 1$ & Masyarakat \\
\hline Laki-laki & 37 & S1 & Masyarakat \\
\hline Laki-laki & 25 & SMA & Masyarakat \\
\hline Perempuan & 24 & S1 & Masyarakat \\
\hline
\end{tabular}

Pendidikan informan penyintas COVID19, keluarganya dan masyarakat sekitarnya pada umumnya tinggi, yaitu sarjana walaupun ada yang berpendidikan SMA. Usia informan penelitian berkisar antara 24-61 tahun.

Berdasarkan hasil wawancara kepada penyintas, keluarga penyintas, dan masyarakat diperoleh hasil sebagai berikut. 


\section{Perasaan Penyintas Saat Dinyatakan Positif Covid-19}

Mayoritas informan merasa bingung dan hampir tidak percaya ketika hasil menunjukkan bahwa mereka mengalami COVID-19, karena penyakit COVID-19 yang diderita tidak bergejala. Seorang informan merasa panik dan putus asa setelah dinyatakan positif Covid-19 hingga mengalami penurunan kondisi kesehatan, ditambah lagi orang tuanya juga terkena Covid-19 dan memiliki komorbid. Berikut adalah beberapa pernyataan dari informan:

"Ketika dinyatakan positif saya merasa bingung, sedikit kaget dan merasa gak percaya juga karena tanpa ada gejala apapun sebelumnya. Saya merasa sedih juga.." (Informan 1)

"Langsung down, stress, apalagi setelah saya sadar bahwa di rumah yang punya gejala duluan saya dan saya juga punya orang tua dengan riwayat penyakit gula." (Informan 2)

"Sedih, panik, dan sempat putus asa karena gak tau kedepannya akan gimana." (Informan 3).

\section{Stigma Terhadap Penyintas COVID-19}

Mayoritas informan menyatakan bahwa mereka merasa mendapatkan stigma dari masyarakat setelah terinfeksi COVID-19. Salah satu informan menyatakan bahwa teman-temannya masih takut bertemu dengan dirinya bahkan setelah menjadi penyintas. Informan lain juga menyatakan bahwa temantemannya tidak pernah menghubungi dirinya serta perlahan menjauh darinya walaupun telah dinyatakan negatif dari COVID-19. Salah satu tetangga informan juga menyemprotkan disinfektan ketika informan melewati depan rumahnya. Berikut adalah beberapa pernyataan dari informan:

"teman saya masih takut untuk bertemu dengan saya setelah saya sembuh dari COVID-19” Informan 3)

“..awal saya terinfeksi COVID-19 di rumah saya memang disemprot disinfektan dan saya mikirnya kalau itu adalah hal yang bagus dan tepat untuk dilakukan, tetapi ternyata hal tersebut terjadi juga pada ibu saya dan mbak di rumah. Setelah saya sembuh pun, tetangga saya selalu menyemprotkan disinfektan setiap kali kami melewati rumah mereka." (Informan 2)

Hanya ada seorang informan menyatakan bahwa ia tidak merasa mendapatkan stigma. Hal ini ditunjukkan dari bantuan dan perhatian yang diberikan oleh teman maupun tetangganya ketika dirinya sedang melakukan isolasi mandiri di rumah. Teman dan tetangganya sangat mendukung kesembuhan dirinya dengan selalu menanyakan bagaimana keadaannya dan selalu mengirimkan makanan untuknya.

"saya tidak mendapatkan stigma dari teman maupun masyarakat disekitar saya, mereka malah sangat peduli dan mendukung kesembuhan saya dengan selalu menanyakan kabar, memberikan saya vitamin dan mengirim makanan lewat ojek online tapi kalau sama tetangga biasanya ditaruh di pager rumah" (Informan 1)

\section{Stigma Terhadap Keluarga Penyintas COVID-19}

Menurut informan keluarga penyintas COVID-19, dua informan menyatakan bahwa mereka juga mendapatkan stigma dari masyarakat. Mereka menyatakan bahwa masyarakat di lingkungan tempat tinggalnya menjauhi dirinya saat ia ingin membeli sayur atau membeli kebutuhan rumah tangga di sebuah toko yang tidak jauh dari rumahnya. Selain itu, ketika ia melewati rumah tetangganya mereka juga menyemprotkan disinfektan seperti yang tergambar pada kutipan pernyataan di bawah ini:

"Iya sedikit. Beberapa orang dilingkungan saya sedikit menjaga jarak dengan saya. Saya pernah waktu itu lagi belanja sayur terus ada tetangga dan mereka langsung kayak yang beli cepet-cepet terus pergi.". (Informan 6)

"Iya saya merasa dapat stigma dari tetangga saya. Waktu itu saya pernah mau beli gas di warung dekat dengan rumah saya, trus yang jual bilang kalau gasnya habis dan beberapa menit kemudian ada orang yang membeli gas dan ternyata ada. Terus pernah juga pas saya lagi lewat di gang dekat dengan rumah saya 
terus langsung disemprot disinfektan sama tetangga dan itu juga berlangsung setelah anak saya sembuh..". (Informan 5)

Hanya satu orang informan yang menyatakan bahwa ia tidak mendapatkan stigma dari masyarakat, bahkan lingkungan sekitarnya sama sekali tidak menjauhi dirinya, tetap berlaku seperti biasa namun tetap menerapkan protokol kesehatan.

"saya gak merasa dapet stigma sih karena selama anak saya sakit di rumah, tetangga saya pada biasa aja dan tidak menjauhi maupun menghindar dari saya cuma ya tetep nerapin prokes kayak biasa” (Informan 4)

\section{Persepsi Masyarakat Terhadap Penyintas COVID-19}

Mayoritas informan menyatakan bahwa penyintas COVID-19 tidak perlu dijauhi. Hal ini disebabkan karena dari penyintas COVID19, masyarakat dapat mengetahui banyak informasi seperti dugaan penyebab COVID19 dan para penyintas yang dinyatakan sembuh sudah dapat melakukan aktivitas secara normal dengan tetap menerapkan protokol kesehatan. Berikut adalah adalah beberapa pernyataan dari informan:

"Tentunya penyintas tidak perlu dihindari/diasingkan karena dari mereka kita bisa mendapatkan berbagai informasi kayak misalnya dugaan penyebab terkena covid, dll." (Informan 7)

"Penyintas COVID-19 tidak perlu dijauhin karna mereka juga sudah dinyatakan sembuh dan bisa beraktivitas normal." (Informan 10)

Namun, ada seorang informan yang menyatakan bahwa harus menjauhi penyintas COVID-19 karena mereka masih memiliki potensi untuk menularkan COVID-19 ke masyarakat, seperti penyataan berikut ini:

"Menurut saya penyintas COVID-19 perlu untuk dijauhin karna bagaimanapun pasti mereka memiliki potensi untuk menularkan COVID-19 pada kita." (Informan 9)

\section{Persepsi Masyarakat Terhadap Keluarga Penyintas COVID-19}

Seorang informan menyatakan bahwa keluarga dari penyintas COVID-19 tidak perlu dijauhi apabila sudah melakukan swab PCR dan hasilnya negatif. Sedangkan satu informan yang lain juga menyatakan hal serupa namun harus tetap menjaga jarak dan membatasi interaksi sesuai dengan anjuran melaksanakan protokol kesehatan.

"Ada beberapa kondisi yg perlu di perhatikan, kalau penderita isoman di rumah dengan keluarga yang tidak covid dan keluarga tersebut sudah PCR dan menunjukkan hasil negatif dan tidak ada gejala, maka ya ga perlu dijauhi." (informan 7)

"Kalo keluarganya sih gak masalah sama sekali dan gak perlu dijauhi tapi kita juga harus membatasi interaksi." (Informan 8)

Hal yang berbeda dikemukakan oleh seorang informan yang menyatakan bahwa keluarga penyintas COVID-19 perlu dijauhi karena sudah pernah melakukan kontak baik secara langsung dan tidak langsung dengan penderita COVID-19, sebagaimana kutipan di bawah ini:

"Keluarga penyintas COVID-19 perlu dijauhi karna pastinya keluarga penyintas COVID-19 sudah pernah melakukan kontak baik secara langsung maupun tidak langsung dengan penderita COVID-19." (Informan 9)

\section{Tanggapan Masyarakat Tentang Adanya Diskriminasi Terhadap Penyintas COVID- 19}

Dari keempat informan yang diwawancarai, satu dari empat orang menyatakan bahwa terjadinya diskriminasi terhadap penyintas COVID-19 adalah hal yang wajar karena mengingat penularan COVID-19 sangat cepat dan ditularkan oleh manusia juga.

"Menurut saya hal diskriminasi yang dilakukan oleh masyarakat lainnya wajar dilakukan mengingat COVID-19 ini sangat mudah menular." (Informan 4) 
Ketiga informan lainnya menyatakan bahwa tidak perlu melakukan diskriminasi karena hal tersebut merupakan tindakan yang salah. Selain itu, juga sudah banyak orang yang pulih dari COVID-19 dan masyarakat dapat menggali lebih banyak informasi tentang COVID-19.

"Kalau menurut saya sih masyarakat tidak perlu sampai melakukan diskriminasi karena bagaimanapun juga sudah banyak orang yang bisa sembuh dari COVID-19 dan bisa beratktifitas seperti biasa lagi.. Masyarakat juga perlu edukasi lebih lanjut... Sehingga penyintas COVID-19 terbuka akan sebab terkena covid dan bagaimana cara pencegahan langsung dari yang terkena..." (Informan 7)

"Tindakan diskriminasi adalah tindakan yang salah karena bagaimanapun juga status mereka sekarang sudah sembuh dan normal. Apalagi penyintas malah memiliki imunitas yang lebih baik." (Informan 10)

\section{PEMBAHASAN}

COVID-19 sudah banyak menyebabkan kematian di Indonesia. Penularan virus yang ditularkan dari manusia menjadi penyebab ketakutan dan kecemasan di masyarakat sehingga menimbulkan persepsi yang buruk (Dehkordi et al., 2020). Stigma merupakan sesuatu yang dianggap bernilai negatif terhadap suatu keadaan atau kondisi. Stigma di masyarakat biasanya selalu ditandai dengan melekatnya anggapan negatif terhadap seseorang untuk mengetahui krakteristik atau penilaian terhadap orang lain (Abudi et al., 2020). Hasil penelitian ini mendapatkan perasaan penyintas pada saat dinyatakan positif COVID-19 yaitu merasa sedih, cemas karena takut menularkan ke orang lain dan ketakutan memikirkan bagaimana dirinya di masa yang akan datang. Penelitian ini sejalan dengan penelitian di Iran dimana para pasien yang terinfeksi COVID-19 merasakan ketakutan akan kematian, depresi, cemas, dan ketakutan akan menularkan penyakitnya kepada keluarga yang memiliki riwayat penyakit yang sudah didertanya atau komorbid (Baldassarre et al., 2020).

Berdasarkan hasil penelitian ini, informan merasa sedih, bingung, takut akan menularkan ke orang tuanya yang mempunyai riwayat penyakit dan juga takut memikirkan masa depannya akan seperti apa. Hal ini sejalan dengan penelitian yang dilakukan di Iran yang menyatakan bahwa informan takut menularkan virus COVID-19 kepada keluarganya dan juga $75 \%$ informan merasa khawatir dengan masa depan mereka dikemudian hari (Baldassarre et al., 2020). Stigma adalah penyebab utama diskriminasi dan pengucilan, mempengaruhi harga diri individu, mengganggu hubungan keluarga, dan membatasi kemampuan mereka untuk bersosialisasi dan mendapatkan tempat tinggal dan pekerjaan (Oktaviannoor et al., 2020). Menurut penelitian Dwinantroaji, pada beberapa penelitian menurut menunjukkan bahwa pasien yang dinyatakan positif COVID-19 menghadapi stigma berbahaya, bahkan pada beberapa kasus, berujung pada penggusuran, pengabaian, dan konsekuensi lainnya (Dwinantoaji \& DW, 2020).

Para penderita dari beberapa penyakit tertentu sering mendapatkan stigma yang memberikan rasa rendah diri (Setiawati et al., 2020). Mayoritas informan penyintas merasa mendapatkan stigma karena beberapa teman dari informan masih takut bertemu dengannya walau sudah dinyatakan sembuh. Hal ini sejalan dengan penelitian di Indonesia bahwa stigma menjadi penyebab utama munculnya diskriminasi, memengaruhi ketidakpercayaan diri seseorang, mengganggu hubungan keluarga, serta membatasi penyintas untuk bersosialisasi dan memperoleh tempat tinggal serta pekerjaan (Sulistiadi et al., 2020).

Selain penyintas, mayoritas keluarga penyintas juga merasa mendapatkan stigma karena orang-orang yang tinggal di lingkungannya menjauhi mereka. Kondisi ini sejalan dengan penelitian di Ghana yang mendapatkan bahwa ada suatu toko yang menolak untuk menjual barang apapun kepada keluarga penyintas. Selain itu, rumah penyintas dan keluarganya dinamakan "Rumah COVID-19" dan masyarakat 
disekitarnya tidak menginginkan mereka kembali ke rumah walaupun telah dinyatakan negatif COVID-19 (Kwesi \& Asare, 2020).

Timbulnya stigma pada penyintas dan keluarga penyintas COVID-19 dapat disebabkan oleh kurangnya informasi dari lingkungan sosial (Sulistiadi et al., 2020). Stigma sosial dapat disebabkan oleh kurangnya pengetahuan tentang COVID-19 (bagaimana penyakit ditularkan dan diobati, dan bagaimana mencegah infeksi). Terjadinya stigma menyebabkan masyarakat menjadi takut akan tingginya risiko penularan, kurangnya informasi dan timbulnya misinformasi terkait COVID-19. Untuk itu, informasi harus disebarluaskan agar masyarakat tidak memberikan stigma kepada penyintas dan keluarga penyintas (Dwinantoaji \& DW, 2020).

Mayoritas informan menyatakan bahwa baik penyintas maupun keluarga dari penyintas tidak perlu dijauhi karena mereka sudah dinyatakan sembuh dan dapat kembali beraktivitas dengan normal. Penelitian ini sejalan dengan penelitian di Kota Banjarmasin yang menyatakan bahwa sebagian besar responden tidak memberikan stigma karena memiliki pengetahuan yang cukup (Oktaviannoor et al., 2020). Masyarakat Kecamatan Duren Sawit merasa tidak memberikan stigma kepada penyintas COVID-19 di lingkungannya tetapi penyintas sendiri yang takut untuk membuka diri sehingga menyembunyikan penyakitnya.

Sejalan dengan penelitian di Wuhan, Cina bahwa emosi negatif seperti ketakutan akan kematian dan menularkan kepada anggota keluarga lainnya, depresi, stres dan kecemasan, perasaan bersalah dan marah, kekhawatiran pekerjaan, harapan hidup yang rendah dan perkiraan masa depan yang tidak dapat diprediksi dipandang negatif pada penderita COVID-19 (Yuan et al., 2021). Hasil penelitian di India menyatakan bahwa dibutuhkan peran professional untuk kesehatan mental yang dilibatkan dalam menangani pasien COVID-19 mulai dari skrining, saat isolasi bahkan sampai dinyatakan sembuh atau menjadi penyintas (World Health Organization, 2020).
Hasil penelitian di Kecamatan Duren Sawit menunjukkan bahwa SATGAS COVID-19 belum melakukan sosialisasi secara merata untuk menekan diskriminasi terhadap penyintas COVID-19. Hasil penelitian di Denpasar mendapatkan hal tersebut disebabkan karena masih adanya kendala dari kinerja SATGAS COVID-19 yang salah satunya disebabkan karena masih rendahnya kualitas Sumber Daya Manusia (SDM) terkait tentang pengetahuan hukum dan protokol kesehatan COVID-19 (Yanti et al., 2020).

\section{KESIMPULAN}

Timbulnya rasa khawatir dan cemas pada penyintas hanya dirasakan pada saat mereka terpapar virus COVID-19. Stigma negatif dirasakan pada penyintas dan keluarga penyintas COVID-19 serta terdapat tetangga yang memberikan stigma dengan melakukan penyemprotan disinfektan setiap kali penyintas maupun keluarga penyintas COVID-19 melewati rumah mereka. Peranan pemerintah, praktisi kesehatan, dan tokoh masyarakat dalam memberikan edukasi terkait COVID-19 dibutuhkan agar masyarakat tetap mendukung dan tidak memberi stigma negatif kepada penyintas COVID-19.

\section{UCAPAN TERIMAKASIH}

Terima kasih kepada masyarakat di Kecamatan Duren Sawit yang telah bersedia untuk meluangkan waktu pada penelitian ini.

\section{DAFTAR PUSTAKA}

Abudi, R., Mokodompis, Y., \& Magulili, A. N. (2020). STIGMA TERHADAP ORANG POSITIF COVID-19 (Stigma Against Positive People Covid-19). Jambura Journal of Health Sciences and Research, 2(2), 77-84. https://papers.ssrn.com/sol3/papers.cfm?a bstract_id=3582624

Badan Pusat Statistik. (2020). Duren Sawit 
Dalam angka. 93.

Baldassarre, A., Giorgi, G., Alessio, F., Lulli, L. G., Arcangeli, G., \& Mucci, N. (2020). Stigma and discrimination (Sad) at the time of the sars-cov-2 pandemic. International Journal of Environmental Research and Public Health, 17(17), 129.

https://doi.org/10.3390/ijerph17176341

Dai, N. F. (2020). Stigma Masyarakat Terhadap Pandemi Covid-19. Prodi Ilmu Keperawatan Universitas Indonesia Timur, 66-73.

Dehkordi, M. A., Eisazadeh, F., \& Aghajanbigloo, S. (2020). Psychological consequences of patients with coronavirus (COVID- 19): A Qualitative Study. Iranian Journal of Health Psychology, 2(2), 9-20. www.sums.ac.

Dwinantoaji, H., \& DW, S. (2020). Human security, social stigma, and global health: the COVID-19 pandemic in Indonesia. Journal of Thee Medical Sciences (Berkala Ilmu Kedokteran), 52(03), 158165.

https://doi.org/10.19106/jmedscisi005203 202014

Islam, A., Pakrashi, D., Vlassopoulos, M., \& Wang, L. C. (2021). Stigma and misconceptions in the time of the COVID-19 pandemic: A field experiment in India. Social Science and Medicine, 278(March),

113966. https://doi.org/10.1016/j.socscimed.2021. 113966

Izham, A. (2021). Pengaruh Kondisi Sosial Demografi dengan Penanganan Pandemi Covid-19 di Indonesia. https://www.mediasulsel.com/pengaruhkondisi-sosial-demografi-denganpenanganan-pandemi-covid-19-diindonesia/

Kementrian Kesehatan RI. (2021). Data Pemantauan COVID-19 DKI Jakarta. https://corona.jakarta.go.id/id/datapemantauan

Kwesi, N., \& Asare, O. (2020). Stigma as a
Social Death for COVID-19 Survivors in Ghana. May, 0-6.

Lai, C. C., Shih, T. P., Ko, W. C., Tang, H. J., \& Hsueh, P. R. (2020). Severe acute respiratory syndrome coronavirus 2 (SARS-CoV-2) and coronavirus disease2019 (COVID-19): The epidemic and the challenges. International Journal of Antimicrobial Agents, 55(3), 105924. https://doi.org/10.1016/j.ijantimicag.2020 .105924

Laras Widyaningrum, G. (2020). WHO Tetapkan COVID-19 Sebagai Pandemi Global, Apa Maksudnya? https://nationalgeographic.grid.id/read/13 2059249/who-tetapkan-covid-19-sebagaipandemi-global-apa-maksudnya

Mahmud, A., \& Islam, M. R. (2020). Social Stigma as a Barrier to Covid-19 Responses to Community Well-Being in Bangladesh. International Journal of Community Well-Being. https://doi.org/10.1007/s42413-02000071-w

Mashabi, S. (2020). Mobilitas Penduduk DKI yang Tinggi Sebabkan Peningkatan Kasus Covid-19. Kompas.Com. https://nasional.kompas.com/read/2020/0 3/17/17244001/mobilitas-penduduk-dkiyang-tinggi-sebabkan-peningkatan-kasuscovid-19

Oktaviannoor, H., Herawati, A., Hidayah, N., Martina, M., \& Hanafi, A. S. (2020). Pengetahuan dan stigma masyarakat terhadap pasien Covid-19 dan tenaga kesehatan di Kota Banjarmasin. Dinamika Kesehatan: Jurnal Kebidanan Dan Keperawatan, 11(1), 98-109. https://doi.org/10.33859/dksm.v11i1.557

Pemprov DKI Jakarta. (2021). Jakarta Tanggap COVID-19. https://corona.jakarta.go.id/id

Rahman, N. E., Tyas, A. W., \& Nadhilah, A. (2021). Hubungan Pengetahuan Tentang Covid-19 Terhadap Sikap Stigma Masyarakat Pada Orang Yang Bersinggungan Dengan Covid-19. Share: Social Work Journal, 10(2), 209. 
https://doi.org/10.24198/share.v10i2.2961

4

Setiawati, L., Sariti, I., \& Livana, P. (2020). Stigma dan perilaku masyarakat pada pasien positif covid-19. Jurnal Gawat Darurat, 2(2), 95-100.

Sulistiadi, W., Rahayu, S., \& Harmani, N. (2020). Handling of public stigma on covid-19 in Indonesian society. Kesmas, 15(2), 70-76. https://doi.org/10.21109/KESMAS.V15I2 .3909

WHO. (2020). Penyakit infeksi emerging akibat virus, termasuk COVID-19: metode deteksi, pencegahan, respons dan pengendalian.

https://openwho.org/courses/pengantarCOVID-19

World Health Organization. (2021). Coronavirus (COVID-19) data. https://www.who.int/data/

World Health Organization (WHO). (2020). Social Stigma associated with COVID-19 A guide to preventing and addressing. February, 1-5. https://www.who.int/docs/defaultsource/coronaviruse/covid19-stigmaguide.pdf

Yanti, N. P. E. D., Nugraha, I. M. A. D. P., Wisnawa, G. A., Agustina, N. P. D., \& Diantari, N. P. A. (2020). Gambaran Pengetahuan Masyarakat tentang Covid19 dan Perilaku Masyarakat di Masa Pandemi Covid-19. Jurnal Keperawatan Jiwa, Vol. 8 No.(3), 485-490.

Yuan, Y., Zhao, Y. J., Zhang, Q. E., Zhang, L., Cheung, T., Jackson, T., Jiang, G. Q., \& Xiang, Y. T. (2021). COVID-19related stigma and its sociodemographic correlates: a comparative study. In Globalization and Health (Vol. 17, Issue 1). https://doi.org/10.1186/s12992-02100705-4 